\title{
Agronomic, Water Productivity and Economic Analysis of Irrigated Rice under Different Nitrogen and Water Management Methods
}

\author{
Abdulai Yakubu' ${ }^{1}$, Joseph Ofori' ${ }^{2}$, Christiana Amoatey${ }^{1}$, Davie M. Kadyampakeni ${ }^{3}$ \\ ${ }^{1}$ School of Graduate Studies, University of Ghana, Accra, Ghana \\ ${ }^{2}$ Soil and Irrigation Research Centre (SIREC), University of Ghana, Ghana \\ ${ }^{3}$ Institute of Food and Agricultural Sciences, University of Florida, Gainesville, USA \\ Email: abyak2008@gmail.com
}

How to cite this paper: Yakubu, A., Ofori, J., Amoatey, C. and Kadyampakeni, D.M. (2019) Agronomic, Water Productivity and Economic Analysis of Irrigated Rice under Different Nitrogen and Water Management Methods. Agricultural Sciences, 10, 92-109. https://doi.org/10.4236/as.2019.101008

Received: December 9, 2018

Accepted: January 18, 2019

Published: January 21, 2019

Copyright $\odot 2019$ by author(s) and Scientific Research Publishing Inc. This work is licensed under the Creative Commons Attribution International License (CC BY 4.0).

http://creativecommons.org/licenses/by/4.0/

\begin{abstract}
The most limiting factors for irrigated rice farming are water and nitrogen. Efficient water and nitrogen management has remained critical for sustainable rice production in irrigated rice farming system. Due to rapid global population growth and climate change, future rice production will depend heavily on developing strategies and practices that use water and nitrogen efficiently. The study therefore set to evaluate agronomic, water productivity and economic analysis of irrigated rice under various nitrogen and water management methods. To achieve the set objectives, field and pot experiments were carried out at the Soil and Irrigation Research Centre, University of Ghana, Kpong in 2015 and 2016 cropping season. The field experiment was laid in a split plot design with water management treatments as main plots and $\mathrm{N}$ fertilizer as subplot treatment. The pot experiment was carried out in a randomized complete block design with five replications. The water management treatments were; continuous submergence (SC), alternate wet and dry soil condition (AWD) and moist soil condition (MC). Nitrogen fertilizer rates were; no $\mathrm{N}$ fertilizer (N0), $60 \mathrm{~kg} \mathrm{~N} / \mathrm{ha}(\mathrm{N} 1)$ and $90 \mathrm{~kg} \mathrm{~N} / \mathrm{ha}(\mathrm{N} 2)$. Data such as yield and yield parameters of rice, water use, water productivity, costs and returns were recorded. Results obtained from both pot and field experiments revealed that rice yields were at par in AWD and SC but yields were lower in MC treatment. With $\mathrm{N}$ fertilizer, higher yields were observed with $90 \mathrm{~kg} \mathrm{~N} / \mathrm{ha}$. The interaction effect of submerged with $90 \mathrm{~kg} \mathrm{~N} / \mathrm{ha}$ gave the highest grain yield. $\mathrm{N}$ fertilizer effect on water use and water productivity was ranked as $\mathrm{N} 2>\mathrm{N} 1>\mathrm{N} 0$ while water management effect on water use and water productivity was ranked in this order: $\mathrm{SC}>\mathrm{AWD}>\mathrm{MC}$ and $\mathrm{MC}>$ AWD $>$ SC respectively.
\end{abstract}




\section{Keywords}

Irrigated Rice, Nitrogen, Water Management, Yield, Water Productivity

\section{Introduction}

Rice (Oryza sativa L.) is one of the most consumed cereal crop in most of parts of the world. It is said to be a staple crop for more than half of the world's population [1]. About 79 million ha of irrigated lowlands account for $75 \%$ of the global rice production [2]. In Ghana, rice is considered to be the second most important contributor of food security next to maize [3] and the 5th most important source of energy in the diet accounting for 9 percent of total caloric intake [4].

The rice sector is not only the major contributor of food security but also the biggest consumer of freshwater resources. Researchers [5] observed that, lowland rice consumes large volumes of water than any other irrigated crop and it requires up to 2 - 3 times more water compared to other crops.

It is widely acknowledge that rice is grown under continuous submergence to counter nutrient, water and weed stresses by pumping water from the rivers and their tributaries by either small diesel pumps or large electric pumping systems which intern reduce water productivity and farmers' income [6]. Water and energy has therefore emerged to be key elements of sustainability of rice production.

Also, $\mathrm{N}$ nutrition drives rice production but there is a spiral increase $(50 \%)$ in inorganic fertilizer prices in Ghana due to fall of the local currency on exchange market, increase in fuel prices and the removal of government subsidies on fertilizer price [7]. In effect, majority of Ghanaian farmers are unable to apply fertilizer at the required rate for a good crop yield. In addition to high cost of fertilizers, poor nitrogen and water management have also resulted in serious drawbacks in rice production by small-holder farmers who form the majority of the farming population. As a result, fertilizer and water often represent the most expensive input cost for irrigated rice farming.

Furthermore, decreasing water availability for agriculture threatens the production of rice in irrigated system. Worldwide, fresh water resources are threatened by rapid global population growth and climate change. Due to growing demand for water resources from all sectors, it is projected that by 2025, some countries in Sub-Sahara Africa (SSA) including Ghana will face water stress [8]. Water management is therefore critical for sustainable rice production in irrigated rice farming system.

In order to improve water use efficiency and water productivity in irrigated rice, many water management techniques have been proposed [9] [10] [11] [12]. However, considering the spiraling increase in cost of chemical fertilizer and huge competition for water for industrial, domestic and agricultural use, it is es- 
sential to identify the most efficient water management methods and optimum $\mathrm{N}$ fertilizer level for sustainable increase in rice productivity in irrigated rice farming system in Ghana. Against this backdrop, this work seeks to evaluate agronomic, water productivity and economic analysis of irrigated rice farming under different $\mathrm{N}$ levels and water management methods in that only the most cost-effective technologies that mirror the economic capabilities of the Ghanaian farmer can be promoted.

\section{Materials and Methods}

\subsection{Description of the Study Area}

The experiments were carried out at the Soil and Irrigation Research Centre (SIREC) of the University of Ghana in 2015 and 2016 cropping season. Geographically, the experimental area is located between latitudes $\left(00^{\prime} 04^{\prime \prime} \mathrm{E}, 60^{\prime} 09^{\prime \prime} \mathrm{N}\right)$, in the Eastern region of Ghana. It is part of the Accra plains and has annual rainfall between 800 and $1100 \mathrm{~mm}$ with mean annual temperature of $28^{\circ} \mathrm{C}$. The soils of the experimental site are vertisols, which are characterised by montmorillonitic clay minerals with clay content of 35\% - 40\%. Initial chemical characteristics of soils of the experimental site $(0-20 \mathrm{~cm}$ depth) are indicated in $\mathrm{Ta}$ ble 1 .

\subsection{Land and Pot Preparation}

The land was prepared by ploughing to bury all vegetation, submerged with water and puddled to reduced percolation of water. Experimental units of $2 \mathrm{~m} \times 3 \mathrm{~m}$ were measured out using a measuring tape, garden line and pegs. Sixty $(60) \mathrm{cm}$ high metallic barriers were inserted in each unit at a depth of $30 \mathrm{~cm}$ to prevent lateral movement of nutrient and water in and out of the plots. The size of each of the metallic containers was $2 \mathrm{~m} \times 3 \mathrm{~m}$ and they were sprayed with anti-rust paint to prevent rusting.

For the pot experiment, plastic pots with $10,000 \mathrm{~cm}^{3}$ volume were used. Soil was collected from an uncultivated field at a depth of $0-15 \mathrm{~cm}$ and was crushed and sieved through $2 \mathrm{~mm}$ size mesh to obtain fine earth fraction. Nine kilograms $(9 \mathrm{~kg})$ of the soil was weighed into each plastic pot to attain the field bulk density. The pot experiment was carried out in a randomized complete block design with five replications.

\subsection{Experiment Design and Treatments}

The experiment was carried out in a split plot design with 3 replications. The main plot factors were water management regimes and the sub-plot factors were nitrogen levels. The three water management methods were: alternate wet and dry (AWD), moist soil condition between field capacity and permanent wilting point (MC), and continuous submergence (SC). The nitrogen levels were: 0, 60 and $90 \mathrm{~kg} \mathrm{~N} / \mathrm{ha}$ as subplots within each main plot as indicated in Table 2. The main plots were separated from each other by bunds at a distance of $2 \mathrm{~m}$ whiles 
Table 1. Chemical characteristics of soil at $0-20 \mathrm{~cm}$ depth.

\begin{tabular}{ccccccc}
\hline Depth $(\mathrm{cm})$ & $\mathrm{TN} \%$ & $\mathrm{AP}$ & $\mathrm{AK}\left(\mathrm{mg} \cdot \mathrm{kg}^{-1}\right)$ & $\mathrm{Ca}\left(\mathrm{mg} \cdot \mathrm{kg}^{-1}\right)$ & $\mathrm{pH}$ & $\mathrm{OC} \%$ \\
\hline $0-20$ & 0.067 & 2.09 & 4.72 & 22.83 & 7.55 & 1.55 \\
\hline
\end{tabular}

TN: total nitrogen, AP: available phosphorus, AK: available potassium, Ca: exchangeable calcium, pH: soil reaction, OC: organic carbon.

Table 2. Description of treatments.

\begin{tabular}{cc}
\hline Water management & Nitrogen fertilizer level \\
\hline Alternate wetting and drying (AWD) & No nitrogen fertilizer (N0) \\
Uoist condition between saturation and field capacity (MC) & $90 \mathrm{~kg} \mathrm{~N} / \mathrm{ha}(\mathrm{N} 1)$ \\
& No nitrogen fertilizer (N0) \\
& $60 \mathrm{~kg} \mathrm{~N} / \mathrm{ha}(\mathrm{N} 1)$ \\
& $90 \mathrm{~kg}$ N/ha (N2) \\
Continuous submergence (CS) & No nitrogen fertilizer (N0) \\
& $60 \mathrm{~kg} \mathrm{~N} / \mathrm{ha}(\mathrm{N} 1)$ \\
& $90 \mathrm{~kg} \mathrm{~N} / \mathrm{ha}(\mathrm{N} 2)$ \\
\hline
\end{tabular}

metallic barriers of size $6 \mathrm{~m}^{2}$ were then buried $30 \mathrm{~cm}$ deep in each sub plot to reduce lateral movement of water and nutrients. Rice variety, Ex Baika was used as the test crop. Twenty five days old seedlings were transplanted at spacing of $20 \mathrm{~cm}$ within rows and $20 \mathrm{~cm}$ between rows with 2 seedlings per hill. During planting, all the plots were kept saturated with irrigated water to prevent transplanting shock.

\subsection{Fertilizer Application}

The nitrogen fertilizer source was Urea. Nitrogen fertilizer was applied two times that is $50 \%$ at transplanting and $50 \%$ at panicle initiation. Nitrogen fertilizer levels were 0,60 and $90 \mathrm{~kg} \mathrm{~N} /$ ha henceforth referred to as N0, N1 and N2, respectively. Straight fertilizers of triple Superphosphate $\left(\mathrm{P}_{2} \mathrm{O}_{5}\right)$ and muriate of potash $\left(\mathrm{K}_{2} \mathrm{O}\right)$ was applied at a rate of $45 \mathrm{~kg} / \mathrm{ha}$ to all the plots at transplanting of seedlings.

\subsection{Water Management}

After transplanting, all the plots were irrigated to maintain uniform moisture content at saturation for the first week to ensure full establishment of the seedlings. Perforated PVC pipes of about $3 \mathrm{~cm}$ in diameter and $45 \mathrm{~cm}$ in length were inserted in all except submerged treated plots $15 \mathrm{~cm}$ above and $30 \mathrm{~cm}$ below the soil surface to monitor soil water levels below the soil surface.

Graduated buckets and cylinders were used to apply water to the plots and 
pots, and the quantity of water applied throughout the experiment was recorded. The amount of rainfall (rainfall events) during the experimental period was also recorded. A metre wooden rule was used to measure moisture level below and above the soil surface. Water was maintained at $5 \mathrm{~cm}$ above the soil surface till ten days to harvest in the continuous submerged treatment. For the moist treatment, soil moisture was kept at $18 \mathrm{~cm}$ and $25 \mathrm{~cm}$ below the soil surface in the pot and field experiments, respectively. In the AWD treatment, the experimental unit was only submerged ( $5 \mathrm{~cm}$ above the soil surface) when soil moisture dropped to 18 and $25 \mathrm{~cm}$ below the soil surface in the pots and field experiments, respectively. All the treatments were continuously submerged at booting stage to ten days to harvest.

\subsection{Water Use Measurement}

Water was applied through a horse pipe and the amount of water consumed per plot was measured using containers with known volume. Water application was done using graduated containers (10 and 15 liters). The amount of water-use was obtained from daily measurements. Depth of irrigation water $(\mathrm{mm})$ applied was computed by dividing the volume of water applied by the area of the subplot. Also, amount of precipitation during the period (rainfall events and amounts) were recorded.

\subsection{Data Collection}

Grain yield was determined by weighing grains from $5 \mathrm{~m}^{2}$ and expressed as t/ha at $14 \%$ grain moisture. Ten plants were selected at the center of the plot randomly and used to determine the yield components: test weight, percentage of filled grains, grains/panicle and effective tillers.

Quantification of water productivity and economic analysis of water use

Water productivity was estimated according to [13]. The equation for estimating water productivity is given as;

$$
W P=\frac{G Y}{T W A}
$$

where; $W P=$ water productivity $\left(\mathrm{kg} / \mathrm{m}^{3}\right), G Y=$ grain yield $(\mathrm{kg} / \mathrm{ha})$ and $T W A=$ total water applied (irrigation water and rain water) expressed in $\mathrm{m}^{3} /$ ha. Percentage water saving was obtained with reference to the irrigation water and calculated as the difference in irrigation under the two water management regimes divided by the irrigation water applied under the SC regime expressed as a percentage.

Net returns from sales of rice was calculated as;

$$
\text { Net returns }=\text { Cost of production }- \text { Gross returns }
$$

Benefit cost ratio; $B / C$ was estimated using the formula;

$$
B / C=\frac{\text { Gross returns }}{\text { Cost of cultivation }}
$$




\subsection{Data Analysis}

Data collected were subjected to analysis of variance (ANOVA) to find out the significance difference due to treatments using GenStat (12th Edition). Mean separation was done using least significance difference (LSD) at 5\% level of significance.

\section{Results}

\subsection{Agro-Hydrological Conditions}

The summary for the climatic data presented in Table 3 was recorded at the University of Ghana Soil and Irrigation Research Center agro-meterological station during research period. The total rainfall during the entire period was $396.8 \mathrm{~mm}$. October recorded the highest rainfall while December had the least rainfall. Monthly maximum temperature ranged from $31^{\circ} \mathrm{C}$ in both July and August, 2015 to $34.7^{\circ} \mathrm{C}$ in January, 2016. Mean relative humidity at the experimental site ranged from $23.0 \%$ in December to $62.0 \%$ in October.

\subsection{Results from Pot Experiment}

\subsubsection{Rice Yield and Yield Parameters}

Grain yield was significantly $(\mathrm{p}<0.05)$ influenced by water management and $\mathrm{N}$ fertilizer (Figure 1). Grain yield in AWD was at par with SC water treatment, while MC water treatment produced significantly $(\mathrm{p}<0.05)$ lower grain yield. Differences in yield among the $\mathrm{N}$ levels were in the order: $\mathrm{N} 2>\mathrm{N} 1>\mathrm{N} 0$.

Number of effective tillers/pot was significantly $(\mathrm{p}<0.05)$ influenced by both water management and $\mathrm{N}$ fertilizer (Table 4). Also, the interaction effect of water management and $\mathrm{N}$ fertilizer was significant. Number of effective tillers did not differ significantly $(\mathrm{p}>0.05)$ between AWD and SC water treatments. However both water treatments were significantly superior to MC water treatment.

Number of effective tillers increased with increased $\mathrm{N}$ rate with the lowest number of tillers being recorded in plants treated with no $\mathrm{N}$ fertilizer (N0). Interaction effect of N2 and SC produced higher number of effective tillers followed by $\mathrm{N} 2$ and AWD interaction. In all, N0 with MC interaction was inferior to all other interaction effect. Number of grains/panicle was significantly ( $\mathrm{p}<$ 0.05 ) influenced by water management and $\mathrm{N}$ fertilizer (Table 4). Also, the interaction effect of water management and $\mathrm{N}$ fertilizer on number of grains/panicle was significant $(\mathrm{p}<0.05)$.

AWD and SC produced similar number of grains/panicle however, MC treated plants produced the lowest number of grains/panicle. With response to $\mathrm{N}$ fertilizer, number of grains/panicle increased with increased $\mathrm{N}$ application rate with the lowest number produced in N0. Interaction effect of N2 with SC and N0 with moist produced the highest and lowest number of grains/panicle respectively.

Percentage filled grains ranged from $88.3 \%$ to $93.7 \%$ depending upon treatment combination as indicated in Table 4 . Percentage filled grains was significantly 
Table 3. Total monthly rainfall, mean monthly maximum temperature and humidity of the experimental site during the experimentation.

\begin{tabular}{cccc}
\hline Month & Rainfall $(\mathrm{mm})$ & Maximum temperature $\left({ }^{\circ} \mathrm{C}\right)$ & Relative humidity (\%) \\
\hline July & 97.0 & 31.0 & 37.4 \\
August & 22.3 & 31.0 & 34.9 \\
September & 21.9 & 32.2 & 59.0 \\
October & 106.4 & 32.6 & 62.0 \\
November & 96.0 & 33.8 & 60.2 \\
December & N/A & 34.2 & 23.0 \\
January & 33.2 & 34.7 & 34.7 \\
\hline
\end{tabular}

N/A: not available. Source: Agrometeorological station, SIREC-Kpong.

Table 4. Effective tillers, grains/panicle, \% filled grains and test weight as influenced by nitrogen and water management.

\begin{tabular}{|c|c|c|c|c|c|c|c|c|}
\hline \multirow{2}{*}{ Parameter } & \multirow{2}{*}{ Water mgt. (W) } & \multicolumn{4}{|c|}{ Nitrogen management $(\mathrm{N})$} & \multicolumn{3}{|c|}{ LSD (0.05) } \\
\hline & & No & $\mathrm{N} 1$ & $\mathrm{~N} 2$ & Mean & $\mathbf{N}$ & $\mathrm{W}$ & $\mathrm{N} \times \mathrm{W}$ \\
\hline \multirow[t]{4}{*}{ Effective tillers } & AWD & 15 & 20 & 21 & 19 & & & \\
\hline & MC & 12 & 14 & 18 & 14 & $0.9^{* *}$ & $0.9^{* *}$ & $1.6^{*}$ \\
\hline & CS & 15 & 19 & 22 & 19 & & & \\
\hline & Mean & 14 & 18 & 20 & & & & \\
\hline \multirow[t]{4}{*}{ Grains/panicle } & AWD & 100 & 106 & 134 & 113 & & & \\
\hline & MC & 91 & 95 & 102 & 99 & $4.1^{* *}$ & $4.1^{\star *}$ & $7.1^{*}$ \\
\hline & CS & 103 & 108 & 135 & 115 & & & \\
\hline & Mean & 98 & 103 & 124 & & & & \\
\hline \multirow[t]{4}{*}{$\%$ filled grains } & AWD & 89.3 & 93.7 & 92 & 91.7 & & & \\
\hline & MC & 88.3 & 89 & 90 & 92.6 & $1.3^{*}$ & ns & ns \\
\hline & CS & 91.7 & 93.7 & 92.3 & 89.1 & & & \\
\hline & Mean & 89.8 & 92.1 & 91.4 & & & & \\
\hline \multirow[t]{4}{*}{$\begin{array}{l}1000 \text { grain } \\
\text { weight }(g)\end{array}$} & AWD & 27.4 & 26.9 & 26.5 & 26.8 & & & \\
\hline & MC & 27.1 & 26.6 & 27.1 & 26.9 & ns & ns & ns \\
\hline & CS & 27.3 & 27.5 & 27.4 & 27.4 & & & \\
\hline & Mean & 27.3 & 27 & 27 & & & & \\
\hline
\end{tabular}

AWD: alternate wetting and drying soil condition; MC: moist soil condition between field capacity and permanent wilting point; CS: continuously submerged soil condition; N0, N1 and N2, are 0, 60 and 90 $\mathrm{kg} \cdot \mathrm{N} \cdot \mathrm{ha}^{-1}$ respectively. LSD: least significant difference; ${ }^{*}$ means significant at $5 \%$; ${ }^{* *}$ means significant at $1 \%$; NS means not significant at $5 \%$.

$(\mathrm{p}<0.05)$ influenced by $\mathrm{N}$ fertilizer treatments but not by water management. $\mathrm{N} 2$ and N1 did not differ in percentage filled grains but lowest percentage filled grains was recorded in N0. The interaction of water management and N fertilizer on percentage filled grains was non-significant $(p>0.05)$. 


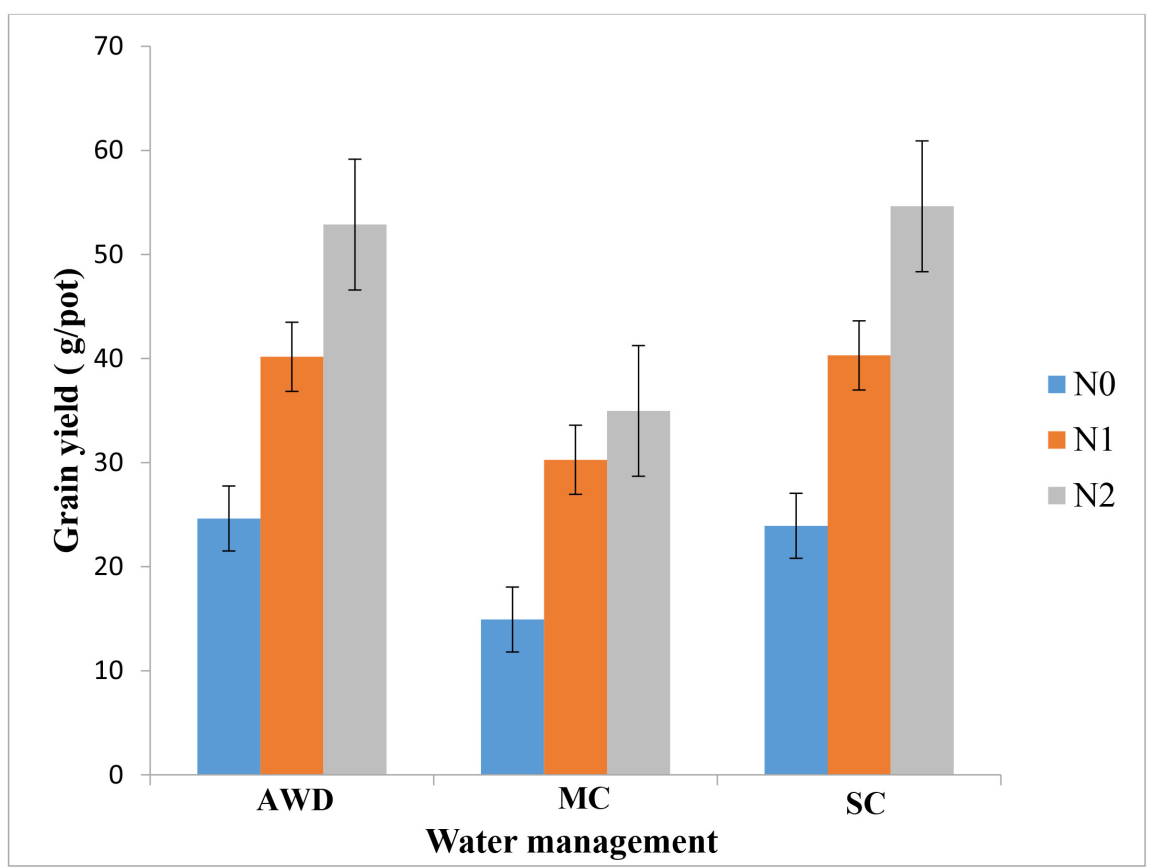

Figure 1. Grain yield of rice as influenced by $\mathrm{N}$ fertilizer and water management. AWD: alternate wetting and drying soil condition; MC: moist soil condition between field capacity and permanent wilting point; CS: continuously submerged soil condition; N0, N1 and $\mathrm{N} 2$, are 0,60 and $90 \mathrm{~kg} \cdot \mathrm{N} \cdot \mathrm{ha}^{-1}$ respectively. Bars represent means \pm SEM of 3 replicates.

Test weight was not significantly ( $\mathrm{p}>0.05$ ) influenced by both $\mathrm{N}$ fertilizer and water management (Table 4). Also, there was no interaction effect of water management and $\mathrm{N}$ fertilizer on test weight.

\subsubsection{Water Use, Percentage Water Saved and Water Productivity}

Water use was significantly $(\mathrm{p}<0.05)$ influenced by both water management and $\mathrm{N}$ fertilizer application rate (Table 5). Interaction effect of water management and $\mathrm{N}$ fertilizer significantly $(\mathrm{p}<0.05)$ influenced water use. For $\mathrm{N}$ fertilizer, the trend of response of water use was $\mathrm{N} 2>\mathrm{N} 1>\mathrm{N} 0$. Water use with regards to water management was ranked in this order: $\mathrm{MC}<\mathrm{AWD}<\mathrm{SC}$.

Nitrogen did not significantly ( $p>0.05$ ) influence percentage of water saved. Also there was no significant $(p>0.05)$ interaction effect between water and nitrogen on percentage water saved.

Percentage of water saved was insignificantly $(\mathrm{p}<0.05)$ higher under MC treatment than AWD treatment. Both water management treatments and $\mathrm{N}$ fertilizer, and their interactions had a significant $(\mathrm{p}<0.05)$ effect on water productivity (Table 5). In all cases, water productivity increased with increased $\mathrm{N}$ fertilizer application rate. In relation to water management treatments, water productivity was ranked in this order: MC > AWD > SC. In general, the interaction effect of N2 with MC water management produced higher $W P$ followed by N1 with same water management. The lowest $W P\left(0.47 \mathrm{~g} \cdot \mathrm{cm}^{-3}\right)$ was observed at N0 with SC interaction. 
Table 5. Water use, percentage water saved and water productivity under various water and nitrogen treatments in rice.

\begin{tabular}{|c|c|c|c|c|c|c|c|c|}
\hline \multirow{2}{*}{ Parameter } & \multirow{2}{*}{$\begin{array}{l}\text { Water mgt. } \\
\text { (W) }\end{array}$} & \multicolumn{4}{|c|}{ Nitrogen management $(\mathrm{N})$} & \multicolumn{3}{|c|}{ LSD (0.05) } \\
\hline & & No & $\mathrm{N} 1$ & $\mathrm{~N} 2$ & Mean & $\mathrm{N}$ & $\mathrm{W}$ & $\mathrm{N} \times \mathrm{W}$ \\
\hline \multirow[t]{4}{*}{$\begin{array}{l}\text { Water use } \\
\left(\mathrm{cm}^{3}\right)\end{array}$} & AWD & 48 & 49.3 & 50.5 & 49.3 & & & \\
\hline & MC & 23.1 & 26.4 & 32 & 27.2 & $0.95^{\star *}$ & $0.96^{* *}$ & $1.66^{*}$ \\
\hline & CS & 50.8 & 53.3 & 57.8 & 54 & & & \\
\hline & Mean & 40.6 & 43 & 46.7 & & & & \\
\hline \multirow[t]{4}{*}{$\begin{array}{c}\text { Percentage } \\
\text { water saved (\%) }\end{array}$} & AWD & 20.4 & 15.5 & 20.8 & 18.3 & & & \\
\hline & MC & 27.9 & 26.5 & 28.3 & 27.8 & NS & $2.7^{* *}$ & NS \\
\hline & CS & - & - & - & - & & & \\
\hline & Mean & 24.2 & 21 & 24.6 & & & & \\
\hline \multirow{4}{*}{$\begin{array}{c}\text { Water } \\
\text { productivity } \\
\left(\mathrm{g} / \mathrm{cm}^{3}\right)\end{array}$} & AWD & 0.51 & 0.82 & 1.05 & 0.79 & & & \\
\hline & MC & 0.65 & 1.06 & 1.09 & 0.96 & $0.3^{\star *}$ & $0.3^{* *}$ & $0.05^{\star *}$ \\
\hline & CS & 0.47 & 0.76 & 0.95 & 0.72 & & & \\
\hline & Mean & 0.55 & 0.91 & 1.03 & & & & \\
\hline
\end{tabular}

AWD: alternate wetting and drying soil condition; MC: moist soil condition between field capacity and permanent wilting point; CS: continuously submerged soil condition; N0, N1 and N2, are 0, 60 and 90 $\mathrm{kg} \cdot \mathrm{N} \cdot \mathrm{ha}^{-1}$ respectively. LSD: least significant difference; ${ }^{*}$ means significant at $5 \%$; ${ }^{* *}$ means significant at $1 \%$; NS means not significant at $5 \%$.

\subsection{Results from Field Experiment}

\subsubsection{Yield and Yield Parameters of Rice}

The effect of various water management and $\mathrm{N}$ fertilizer rate on rice yields is shown in Figure 2. In water management treatments, grain yield in AWD was at par with SC water treatment, while MC water treatment produced significantly $(\mathrm{p}<0.05)$ lower grain yield. Differences in yield among the $\mathrm{N}$ levels were in the order: N2 $>\mathrm{N} 1>\mathrm{N} 0$. With regards to interaction effect, the highest grain yield (6.5 t/ha) was recorded in N2 with SC interaction followed by N2 with AWD interaction which produced grain yield of $6.4 \mathrm{t} / \mathrm{ha}$. The lowest grain yield $(2.2 \mathrm{t} / \mathrm{ha})$ was recorded in N0 treated plants in moist water condition.

Number of panicles $/ \mathrm{m}^{2}$ was significantly $(\mathrm{p}<0.05)$ influenced by water management and $\mathrm{N}$ fertilizer as well as their interactive effect (Table 6). Number of panicles $/ \mathrm{m}^{2}$ in AWD was at par with SC water treatments. However, MC treated plants produced significantly lower panicles $/ \mathrm{m}^{2}$. With regards to $\mathrm{N}$ fertilizer rates, panicles $/ \mathrm{m}^{2}$ varied significantly and was ranked in the order: $\mathrm{N} 2>\mathrm{N} 1>$ N0. Interaction effect of $\mathrm{N} 2$ with submerged produced higher number of panicles $/ \mathrm{m}^{2}$ followed by $\mathrm{N} 2$ and AWD interaction. In all, N0 with moist interaction was inferior to all other interaction effect.

Number of grains/panicle was significantly influenced by water management and $\mathrm{N}$ fertilizer (Table 6). Also, the interaction effect of water management and 


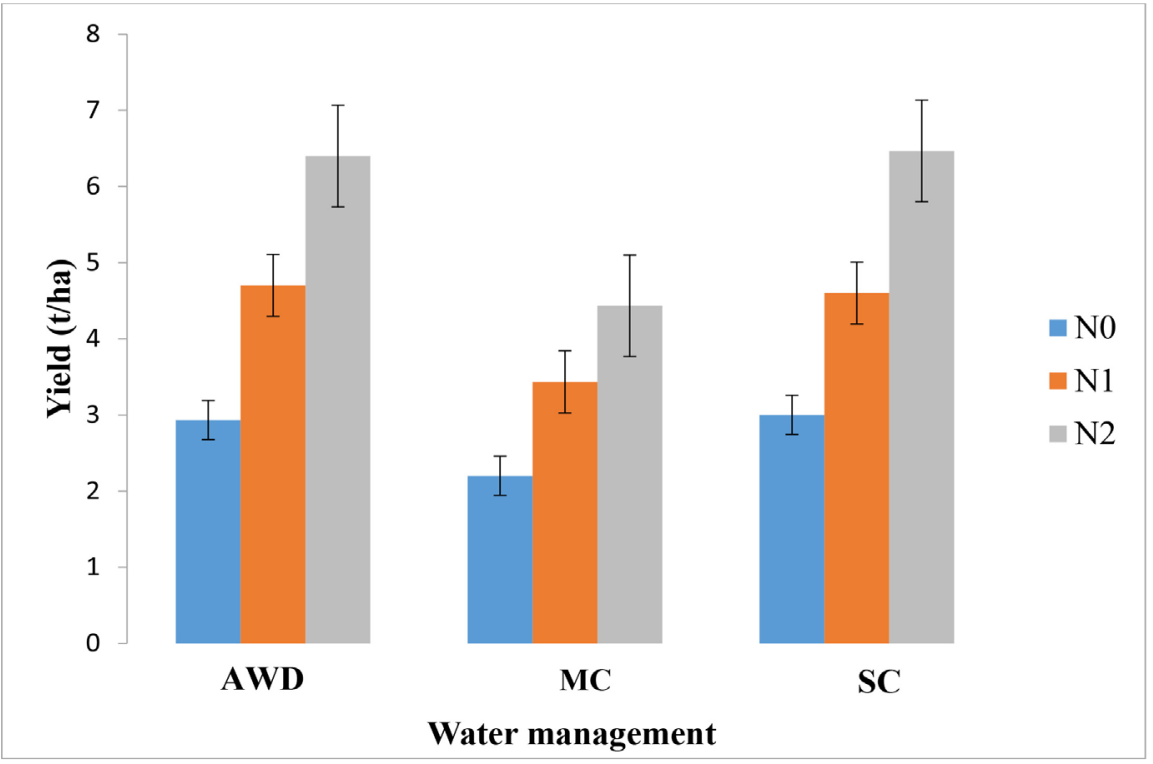

Figure 2. Grain yield of rice as influenced by $\mathrm{N}$ fertilizer and water management. AWD: alternate wetting and drying soil condition; MC: moist soil condition between field capacity and permanent wilting point; CS: continuously submerged soil condition; N0, N1 and $\mathrm{N} 2$, are 0,60 and $90 \mathrm{~kg} \cdot \mathrm{N} \cdot \mathrm{ha}^{-1}$ respectively. Bars represent means \pm SEM of 3 replicates.

Table 6. Panicles $/ \mathrm{m}^{2}$, grains/panicle, \% filled grains and test weight of rice as influenced by water management and nitrogen fertilizer.

\begin{tabular}{|c|c|c|c|c|c|c|c|c|}
\hline \multirow{2}{*}{ Parameter } & \multirow{2}{*}{$\begin{array}{l}\text { Water mgt. } \\
\text { (W) }\end{array}$} & \multicolumn{4}{|c|}{ Nitrogen management $(\mathrm{N})$} & \multicolumn{3}{|c|}{ LSD (0.05) } \\
\hline & & No & N1 & $\mathrm{N} 2$ & Mean & $\mathbf{N}$ & W & $\mathrm{N} \times \mathrm{W}$ \\
\hline \multirow[t]{4}{*}{ panicle $/ \mathrm{m}^{2}$} & AWD & 275 & 369 & 401 & 349 & & & \\
\hline & MC & 232 & 324 & 400 & 319 & $12.3^{* *}$ & $10.2^{* *}$ & $363^{*}$ \\
\hline & CS & 277 & 271 & 403 & 350 & & & \\
\hline & Mean & 261 & 355 & 401 & & & & \\
\hline \multirow[t]{4}{*}{ Grains/panicle } & AWD & 113 & 124 & 147 & 127 & & & \\
\hline & MC & 93 & 98 & 102 & 99 & $2.4^{\star *}$ & $1.1^{* *}$ & $3.4^{\star}$ \\
\hline & CS & 113 & 124 & 148 & 128 & & & \\
\hline & Mean & 106 & 115 & 133 & & & & \\
\hline \multirow[t]{4}{*}{$\%$ filled grains } & AWD & 89 & 91.2 & 92 & 90.9 & & & \\
\hline & MC & 90.3 & 86 & 91 & 92.4 & $1.1^{*}$ & ns & ns \\
\hline & CS & 91.3 & 92 & 94 & 89.1 & & & \\
\hline & Mean & 90.2 & 89.9 & 92.3 & & & & \\
\hline \multirow[t]{4}{*}{$\begin{array}{l}1000 \text { grain } \\
\text { weight }(g)\end{array}$} & AWD & 26.9 & 27.1 & 26.4 & 26.8 & & & \\
\hline & MC & 27.1 & 26.6 & 27.1 & 26.9 & $\mathrm{~ns}$ & ns & ns \\
\hline & CS & 27.2 & 27.5 & 27.4 & 27.4 & & & \\
\hline & Mean & 27.1 & 27.1 & 27 & & & & \\
\hline
\end{tabular}

AWD: alternate wetting and drying soil condition; MC: moist soil condition between field capacity and permanent wilting point; CS: continuously submerged soil condition; N0, N1 and N2, are 0, 60 and 90 $\mathrm{kg} \cdot \mathrm{N} \cdot \mathrm{ha}^{-1}$ respectively. LSD: least significant difference; ${ }^{*}$ means significant at $5 \%$; ${ }^{* *}$ means significant at $1 \%$; NS means not significant at $5 \%$. 
$\mathrm{N}$ rate on number of grains/panicle was significant $(\mathrm{p}<0.05)$. Number of grains/panicle was not significant ( $\mathrm{p}>0.05)$ among AWD and SC treatment but, moist treated plants produced significantly $(\mathrm{p}<0.05)$ lower number of grains/panicle. Based on $\mathrm{N}$ fertilizer, the number of grains/panicle varied in the order: N2 $>\mathrm{N} 1>\mathrm{N} 0$. With interactions, N2 with SC and N0 with MC interaction produced significantly $(\mathrm{p}<0.05)$ higher and lower number of grains/panicle respectively.

Percentage filled grains were significantly influenced $\mathrm{N}$ fertilizer treatments ( $\mathrm{p}$ $<0.05$ ) and ranged from $86.0 \%$ to $94.0 \%$ (Table 6). Interaction effect of water management and $\mathrm{N}$ fertilizer on percentage filled grains was also significant $(\mathrm{p}<$ 0.05 ) but effect of water management on percentage filled grains was not significant ( $p>0.05)$. N2 and N1 did not differ in percentage filled grains but lower percentage filled grains was recorded in N0. Grain filling was poorer in N1 with moist interaction compared to all other treatment interaction.

$\mathrm{N}$ fertilizer and Water management as well as their interaction did not significantly ( $p>0.05$ ) affect 1000 grain weight (Table 6). However, 1000 grain weight ranged from 26.4 to $27.5 \mathrm{~g}$.

\subsubsection{Water Use, Water Productivity and \% Water Saved}

Water use was significantly $(\mathrm{p}<0.05)$ influenced by both water management and $\mathrm{N}$ fertilizer application rate (Table 7). Also, interaction effect of water management and $\mathrm{N}$ fertilizer application on water use was significant. Water use based on total water input (irrigation+ rainfall) ranged from $524 \mathrm{~mm}$ to $1608 \mathrm{~mm}$ depending upon water management and $\mathrm{N}$ rate used. In the case of water management, less water was required to produce rice under AWD than submerged. The least water requirement was observed in moist treatment. In case of $\mathrm{N}$ fertilizer, water use was in the order: $\mathrm{N} 2>\mathrm{N} 1>\mathrm{N} 0$.

Percentage water saved was significantly $(\mathrm{p}<0.05)$ influenced by $\mathrm{N}$ fertilizer and water management as well as their interactive effect (Table 7). MC treatments saved $65 \%$ of water while AWD water management resulted in $34 \%$ water. Percentage water saved decreases with increase in $\mathrm{N}$ fertilizer application rate.

Both water management treatments and $\mathrm{N}$ fertilizer application rates, and their interactions had a significant $(\mathrm{p}<0.05)$ effect on water productivity $(W P)$ of rice (Table 7). $W P$ was greatest in moist followed by AWD treatments. The least $W P$ was recorded in $\mathrm{SC}$ treatments. Among the $\mathrm{N}$ rates, $W P$ varied significantly in this order: $\mathrm{N} 2>\mathrm{N} 1>\mathrm{N} 0$. The highest $W P\left(0.73 \mathrm{~kg} \cdot \mathrm{m}^{-3}\right)$ and lowest $W P\left(0.2 \mathrm{~kg} \cdot \mathrm{m}^{-3}\right)$ were observed at $\mathrm{N} 2$ with moist interaction and N0 with submerged interaction respectively.

\subsubsection{Economic Analysis of Rice}

Generally, N2 fertilizer application rate required the higher cost of production followed by $\mathrm{N} 1$ fertilizer rate while N0 required the lower cost of production (Table 8). In the case of water management, SC required higher cost of production compared to AWD water treatment. MC treatment required least cost of 
Table 7. Water use, Percentage of water saved and Water productivity, as influenced by water management and $\mathrm{N}$ fertilizer.

\begin{tabular}{|c|c|c|c|c|c|c|c|c|}
\hline \multirow{2}{*}{ Parameter } & \multirow{2}{*}{$\begin{array}{l}\text { Water mgt. } \\
\text { (W) }\end{array}$} & \multicolumn{3}{|c|}{ Nitrogen management $(\mathrm{N})$} & \multirow[b]{2}{*}{ Mean } & \multicolumn{3}{|c|}{$\operatorname{LSD}(0.05)$} \\
\hline & & No & N1 & $\mathrm{N} 2$ & & $\mathbf{N}$ & $\mathrm{W}$ & $\mathrm{N} \times \mathrm{W}$ \\
\hline \multirow[t]{4}{*}{$\begin{array}{l}\text { Water use } \\
(\mathrm{mm})\end{array}$} & AWD & 1031 & 1062 & 1132 & 1075 & & & \\
\hline & MC & 524 & 588 & 604 & 572 & $213^{* *}$ & $235^{\star *}$ & $363^{*}$ \\
\hline & CS & 1514 & 1552 & 1608 & 1558 & & & \\
\hline & Mean & 1023 & 1067 & 1115 & & & & \\
\hline \multirow{4}{*}{$\begin{array}{c}\text { Percentage } \\
\text { water saved } \\
\quad(\%)\end{array}$} & AWD & 33.83 & 31.84 & 27.34 & 31 & & & \\
\hline & MC & 66.37 & 62.26 & 61.23 & 65 & $3.4^{* *}$ & $2.1^{\star *}$ & $5.0^{*}$ \\
\hline & CS & - & - & - & - & & & \\
\hline & Mean & 34.33 & 31.51 & 28.43 & & & & \\
\hline \multirow{4}{*}{$\begin{array}{c}\text { Water } \\
\text { productivity } \\
\left(\mathrm{Kg} / \mathrm{cm}^{3}\right)\end{array}$} & AWD & 0.28 & 0.44 & 0.57 & 0.43 & & & \\
\hline & MC & 0.42 & 0.58 & 0.73 & 0.58 & $0.02^{* *}$ & $0.02^{\star *}$ & $0.04^{\star \star}$ \\
\hline & CS & 0.2 & 0.3 & 0.4 & 0.2 & & & \\
\hline & Mean & 0.3 & 0.44 & 0.57 & & & & \\
\hline
\end{tabular}

AWD: alternate wetting and drying soil condition; MC: moist soil condition between field capacity and permanent wilting point; CS: continuously submerged soil condition; N0, N1 and N2, are 0, 60 and 90 $\mathrm{kg} \cdot \mathrm{N} \cdot \mathrm{ha}^{-1}$ respectively. LSD: least significant difference; ${ }^{*}$ means significant at $5 \%$; ${ }^{* *}$ means significant at $1 \%$; NS means not significant at $5 \%$.

production. Cultivation of rice with $\mathrm{N} 2$ under submerged and N0 under moist required the highest and lowest cost of production respectively.

Gross returns increased with increased $\mathrm{N}$ fertilizer application rate regardless of the water management regime (Table 8). The highest gross returns (\$3996.7) were realized when rice was produced under submerged with $\mathrm{N} 2$ fertilizer application rate. In relation to water management treatments, gross return varied in this order: SC > AWD > MC. For interaction effect the lowest gross returns was observed in N0 with moist interaction and the highest gross returns was observed in N2 with submerged interaction.

Average net profit ranged from $\$ 688$ to $\$ 3129.7$ across the treatment combinations (Table 8). In all cases, net profit increased with increased $\mathrm{N}$ fertilizer application rate. The trend of net profit with regard to water treatments was AWD $>$ SC > MC. For interaction effect, the greatest interaction effect on net profit (\$3129.7) was N2 with AWD. Interaction effect of N0 with moist was inferior to other interaction effect of water management and $\mathrm{N}$ fertilizer

In Table 8, $\mathrm{N}$ fertilizer on benefit cost ratio was ranked as: $\mathrm{N} 2>\mathrm{N} 1>\mathrm{N} 0$. In relation to water management, the trend was $\mathrm{AWD}>\mathrm{SC}>\mathrm{MC}$. The interaction effect of N2 with AWD gave the greatest benefit cost ratio. The second highest 
Table 8. Cost of production, gross returns, net profit and benefit cost ratio as influenced by water management and $\mathrm{N}$ fertilizer.

\begin{tabular}{|c|c|c|c|c|c|}
\hline \multirow{2}{*}{ Parameter } & \multirow{2}{*}{ Water mgt. (W) } & \multicolumn{3}{|c|}{ Nitrogen management $(\mathrm{N})$} & \multirow[b]{2}{*}{ Mean } \\
\hline & & No & N1 & N2 & \\
\hline \multirow[t]{4}{*}{$\begin{array}{l}\text { Cost of production } \\
\text { (\$/ha) }\end{array}$} & AWD & 720.6 & 788.8 & 829.6 & 779.6 \\
\hline & MC & 661.8 & 734.1 & 768.5 & 722.1 \\
\hline & CS & 779.1 & 845.7 & 888.4 & 828.8 \\
\hline & Mean & 720.5 & 789.5 & 828.8 & \\
\hline \multirow[t]{4}{*}{ Gross returns $(\$ / \mathrm{ha})$} & AWD & 1812.1 & 2865.2 & 3959.2 & 2878.9 \\
\hline & MC & 1350.6 & 2122.2 & 2739.5 & 2070.8 \\
\hline & CS & 1855.5 & 2843.4 & 3996.7 & 2898.5 \\
\hline & Mean & 1672.8 & 2610.1 & 3565.1 & \\
\hline \multirow[t]{4}{*}{ Net profit $(\$ / \mathrm{ha})$} & AWD & 1091.7 & 2076.4 & 3129.7 & 2099.3 \\
\hline & MC & 688 & 1388.1 & 1971 & 1349.3 \\
\hline & CS & 1076.4 & 1997.8 & 3108.3 & 2060.8 \\
\hline & Mean & 952.4 & 1820.8 & 2736.4 & \\
\hline \multirow[t]{4}{*}{ Benefit cost ratio } & AWD & 1.52 & 2.63 & 3.77 & 0.43 \\
\hline & $\mathrm{MC}$ & 1.04 & 1.89 & 2.56 & 0.58 \\
\hline & CS & 1.38 & 2.36 & 3.50 & 0.20 \\
\hline & Mean & 1.31 & 2.30 & 3.28 & \\
\hline
\end{tabular}

AWD: alternate wetting and drying soil condition; MC: moist soil condition between field capacity and permanent wilting point; CS: continuously submerged soil condition; N0, N1 and N2, are 0, 60 and 90 $\mathrm{kg} \cdot \mathrm{N} / \mathrm{ha}$ respectively. The exchange rate is GHC $4.46=\$ 1.00, \mathrm{GHC}$ is Ghana Cedi, the local currency.

interaction effect was $\mathrm{N} 2$ with SC combination of $\mathrm{N}$ fertilizer and water combination. The lowest benefit cost ratio (1.04) was produced at N0 with moist interaction.

\subsection{Discussion}

\subsubsection{Effect of N Fertilizer on Yield and Yield Parameters of Rice}

Plants fertilized with nitrogen had higher grain yield than unfertilized plants. This could also be attributed to efficient use of split application of nitrogen at transplanting and panicle initiation stage. This is in accordance with [14] who observed that nitrogen fertilizer application increased the activity of cell division and expansion of rice which enhanced grain yield. Also, [15] observed that $\mathrm{N}$ facilitates efficient mobilization of resources and photosynthesis for grain filling. Higher yields in N2 compared to N1 might be due to its higher availability of nitrogen which is essential for rice yields. This is in agreement with other researchers [16] [17] [18] who all observed that the application of $90 \mathrm{~kg} \mathrm{~N} / \mathrm{ha}$ increased rice yield significantly. The finding however, disagrees with [19] who observed that, application of nitrogen fertilizer above $60 \mathrm{~kg} \cdot \mathrm{N} \cdot \mathrm{ha}^{-1}$ did not improve yield. Nitrogen fertilization did not significantly influence test weight of rice. This might be due the fact test weight is a genetic trait and strictly con- 
trolled by the hull of a particular variety and therefore cannot grow above the size allowed by the size of the hull [20].

\subsubsection{Effect of Water Management on Yield and Yield Parameter of Rice}

Yield parameters; panicles $/ \mathrm{m}^{2}$, grains/panicles and test weight were higher in SC treatments though not significantly different from AWD treatments. Nonetheless lower yield parameters contributed in reduced yields as observed in the MC treatments. Grain yield showed no significant differences between SC and AWD treatments. Several authors have cited similar grain between SC and AWD indicating that AWD does not restrict water availability to rice plants. Since AWD plots were submerged at booting stage till ten days before harvest, yield penalties are not recorded. This is consistent with previous studies [17] [21] [22] who all observed similar grain yield between AWD and SC treatments. However, [23] observed higher panicle/ $\mathrm{m}^{2}$ and grain yield under AWD while [24] [25] found conflicting results. The differences in these findings might be due to different soil types, rice variety, climatic conditions as well as duration of irrigation [10]. Plants grown under MC water management had significantly low yields probably due to poor metabolism as a result of its reduced water availability. Furthermore, reduced yields under MC treatment might be due to inhibition of photosynthesis and less translocation of assimilates due to soil low moisture availability [26]. These results are similar to those reported by [17].

Interaction effect of N2 with AWD had similar yield as in submerged and N2 treatment combination. These observations might also be due to more $\mathrm{N}$ transported to the plant when plants were treated with higher doses of N. In all N0 under moist treatment combination gave the lowest grain yield due reduced moisture level at panicle initiation stage, similar to what was reported by [27].

\subsubsection{Effect of Water Management on Water Use, Percentage of Water Saved and Water Productivity}

Submerged water management received higher amount of water use than AWD and moist treatments due to the standing water layer maintained continuously on the plot from crop establishment till ten days to harvest. According to [28] evapotranspiration was intense under continuous submergence. This probably increased the rate of evapotranspiration and percolation in submerged treatments which in turned increased water use.

The highest water productivity was obtained under MC and AWD. AWD had higher water productivity than submerged treatment due to its lower water use. This finding was also reported by [10] [26] [29] who observed that AWD resulted in higher water productivity than continuous submergence of fields. Researchers [30] reported that, continuous submergence produced optimum rice yield however, required the highest amount of water hence low water productivity. MC treatment had the lowest water use and higher water productivity due to the absence of standing water layer from one week after transplanting to booting stage. This conforms to [31] who reported that reduction in water use increased water productivity of rice. Also, MC and AWD resulted in $60 \%$ and $34 \%$ water 
savings respectively compared with SC water management. Likewise, [32] also reported water saving of up to $60 \%$ under AWD compared with SC management.

Interaction effect of N2 and submerged water management required higher water use due to higher evapotranspiration rate as a result of its higher leaf area index and evaporation [28]. With regards to water productivity, N2 treated plants under moist water condition gave higher water productivity compared to the rest of the treatment combinations due to its lower water use. Also [31] reported that reduction in water use increased water productivity of rice.

\subsubsection{Cost-Effectiveness of Water Use under Various Water Management Methods}

The economic analysis from the study revealed that, it was highly economical to produce rice under AWD than the rest of the water management treatments. Although grain yields and gross returns from sales of rice were higher under submerged treatments than AWD water management, cost associated with water under submerged water management reduced net profit since general cost of production was same for all the water treatments. Moist treatment had the highest water productivity but the lowest gross returns from sales of rice due to reduced yields. The outcome agrees with the assertion by [33] [34] who argued that, an increase in water productivity may not result in higher economic benefits. Despite the fact that gross returns was higher in submerged water management than AWD water management, it's economic water use was the least compared to AWD at any given $\mathrm{N}$ rate due to significant water cost associated with this water management regime. Continuous submergence and maintaining moisture level at field capacity does not increase crop and economic water productivity [35].

\subsection{Conclusion}

Results from the study revealed that rice yield differed significantly $(\mathrm{p}<0.05)$ across the various $\mathrm{N}$ and water treatments. Nitrogen application rate of $90 \mathrm{~kg} / \mathrm{ha}$ enhanced plant growth and development culminating to significant increases in grain yields. AWD resulted in similar yields to submerged water treatments and yields of rice were better with interaction effect of $90 \mathrm{~kg} \mathrm{~N} / \mathrm{ha}$ and submerged water treatment. AWD required less water than continuous submergence for rice production and it was more cost-effective to produce rice under AWD than the rest of the water management methods. This indicates that continuous submergence is not an obligation in rice production and farmers could implement AWD and $90 \mathrm{~kg} \mathrm{~N} / \mathrm{ha}$ to reduce water use, and increase water productivity while harvesting maximum yields with reduced cost of production.

\subsection{Recommendation}

Basing on the findings from the study, we recommend that further study on nutrient requirement of irrigated rice in Ghana is needed to investigate more ni- 
trogen rates on different soil types and agro ecological zones. Also, future study should include soil moisture monitoring overtime and to quantify $\mathrm{N}$ leaching because of the high irrigation requirement of rice.

\section{Acknowledgements}

The authors are most grateful to the Office of Research, Innovation and Development (ORID), University of Ghana, for the sponsorship which has been of immense help in funding both the field work and laboratory analysis. We are also grateful to all those who contributed in diverse ways to make this study possible particularly the technical and support staff at the Soil and Irrigation Center (SIREC). This paper is a product of the research work done by the first author for his Master of Philosophy thesis in Crop Science (Agronomy) at the University of Ghana.

\section{Conflicts of Interest}

The authors declare no conflicts of interest regarding the publication of this paper.

\section{References}

[1] Kumar, V., Mukesh, M., Prabhakar, P.K. and Prakash, S. (2015) Physico-Chemical and Cookingg Characteristics of Azad Basmati. International Food Research Journal, 22, 1380-1389.

[2] Maclean, J.L., Dawe, D., Hardy, B. and Hettel, G.P. (2002) Rice Almanac. International Rice Research Institute, Los Baños, 253 p.

[3] MOFA (2009) Evaluation of the Ghana Rice Campaign. A Marketing Campaign implemented by Engineers without Borders and the Ghana Ministry of Food and Agriculture to Stimulate the Rice Value Chain, April 2009.

[4] FAOSTAT (2012) Food and Agriculture Organization of the United Nations Data. Statistical Databases. http://faostat.fao.org/default.aspx?lang=en

[5] Tuong, T.P., Bouman, B.A.M. and Mortimer, M. (2005) More Rice, Less Water-Integrated Approaches for Increasing Water Productivity in Irrigated Rice-Based Systems in ASIA. Plant Production Science, 8, 231-241. https://doi.org/10.1626/pps.8.231

[6] Singh, K.B., Gajri, P.R. and Arora, V.K. (2002) Modelling the Effects of Soil and Water Management Practices on the Water Balance and Performance of Rice. Agricultural Water Management, 49, 77-95. https://doi.org/10.1016/S0378-3774(00)00144-X

[7] MOFA (2014) Agricultural Sector Annual Progress Report. MoFA, 1-115.

[8] UNEP (2008) Vital Water Graphics-An Overview of the State of the World's Fresh and Marine Waters. 2nd Edition, United Nations Environment Programme, Nairobi.

[9] Ramasamy, S.H., Berge, F.M. and Purushothaman, S. (1997) Yield Formation in Response to Drainage and Nitrogen Application. Field Crops Research, 51, 65-82. https://doi.org/10.1016/S0378-4290(96)01039-8

[10] Belder, P., Bouman, B.A.M., Cabangon, R., Guoan, L., Quilang, E.J.P., Yuanhua, L. 
and Tuong, T.P. (2004) Effect of Water-Saving Irrigation on Rice Yield and Water Use in Typical Lowland Conditions in Asia. Agriculture Water Management, 65, 193-210. https://doi.org/10.1016/j.agwat.2003.09.002

[11] Yang, X.G., Bouman, B.A.M., Wang, H.Q., Wang, Z.M., Zhao, J.F. and Chen, B. (2005) Performance of Temperate Aerobic Rice under Different Water Regimes in North China. Agriculture Water Management, 74, 107-122. https://doi.org/10.1016/j.agwat.2004.11.008

[12] Zhang, H., Xue, Y.G., Wang, Z.Q., Yang, J.C. and Zhang, J.H. (2009) An Alternate Wetting and Moderate Soil Drying Regime Improves Root and Shoot Growth in Rice. Crop Science, 49, 2246-2260. https://doi.org/10.2135/cropsci2009.02.0099

[13] Molden, D., Murray-Rust, H., Sakthivadivel, R. and Makin, I. (2003) A Water Productivity Framework for Understanding and Action. In: Kijne, J.W., Barker, R. and Molden, D., Eds., Water Productivity in Agriculture: Limits and Opportunities for Improvement, CAB International, Wallingford, 1-18. https://doi.org/10.1079/9780851996691.0001

[14] Witt, C., Buresh, R., Balasubramanian, V. and Dobermann, D.D. (2002) Improving Nutrient Management Strategies for Delivery in Irrigated Rice in Asia. Better Crops International, 16, 24-31.

[15] Cabangon, R.J., Castillo, E.G. and Tuong, T.P. (2011) Field Crops Research Chlorophyll Meter-Based Nitrogen Management of Rice Grown under Alternate Wetting and Drying Irrigation. Article in Fuel and Energy, 121, 136-146.

[16] Singh, S.P. and Pillai, K.G. (1994) Response to Nitrogen in Semidwarf Scented Rice Varieties. International Rice Research Newsletter, 19, 17.

[17] Mannan, M.A., Bhuiya, M.S.U., Akhand, M.I.M. and Zaman, M.M. (2012) Growth and Yield of Basmati and Traditional Aromatic Rice as Influenced by Water Stress and Nitrogen Level. Journal of Science Foundation, 10, 52-62.

[18] Azarpour, E., Moraditochaee, M. and Bozorgi, H.R. (2014) Effect of Nitrogen Fertilizer Management on Growth Analysis of Rice Cultivars. International Journal of Biosciences, 4, 35-47.

[19] Rezaei, M., Vahed, H.S., Amiri, E., Motamed, M.K. and Azarpour, E. (2009) The Effects of Irrigation and Nitrogen Management on Yield and Water Productivity of Rice. World Applied Sciences Journal, 7, 203-210.

[20] Mae, T. (1997) Physiological Nitrogen Efficiency in Rice: Nitrogen Utilization, Photosynthesis, and Yield Potential. Plant Soil, 196, 201-210. https://doi.org/10.1023/A:1004293706242

[21] Tuong, T.P. (2003) Rice Production in Water-Scarce Environments. In: Kijne, J.W., Barker, R. and Molden, D., Eds., Water Productivity in Agriculture: Limit and Opportunities for Improvement, 53-67. https://doi.org/10.1079/9780851996691.0053

[22] Khairi, M., Nozulaidi, M., Afifah, A. and Jahan, S. (2015) Effect of Various Water Regimes on Rice Production in Lowland Irrigation. Australian Journal of Crop Science, 9, 153-159.

[23] Bouman, B.A.M. and Tuong, T.P. (2001) Field Water Management to Save Water and Increase Its Productivity in Irrigated Rice. Agricultural Water Management, 49, 11-30. https://doi.org/10.1016/S0378-3774(00)00128-1

[24] Marazi, A.R., Khan, G.M., Sing, K.N. and Bali, A.S. (1993) Response of Rice (Oryza sativa) to Different Nitrogen Levels \& Water Regimes in Kashmir Valley. Indian Journal of Agricultural Science, 63, 726-727. 
[25] Awad (2001) Rice Production at the North of Delta Region in Egypt as Affected by Irrigation Intervals and Nitrogen Fertilizer Levels. Journal of Agricultural Sciences, Mansoura University, 26, 1151-1159.

[26] Tabbal, D.F., Bouman, B.A.M., Bhuiyan, S.I., Sibayan, E.B. and Sattar, M.A. (2002) On-Farm Strategies for Reducing Water Input in Irrigated Rice; Case Studies in the Philippines. Agricultural Water Management, 56, 93-112. https://doi.org/10.1016/S0378-3774(02)00007-0

[27] Akram, H.M., Ali, A., Sattar, A., Rehman, H.S.U. and Bibi, A. (2013) Impact of Water Deficit Stress on Various Physiological and Agronomic Traits of Three Basmati Rice (Oryza sativa L.) Cultivars. The Journal of Animal and Plant Sciences, 23, 1455-1423.

[28] Odhiambo, L.O. and Murthy, V.V.N. (1996) Modelling Water Balance Components in Relation to Field Layout in Lowland Paddy Fields, Model Application. Agricultural Water Management, 30, 185-199. https://doi.org/10.1016/0378-3774(95)01214-1

[29] Wardana, I.P., Gania, A.S., Abdulrachman, P.S., Bindraban and Keulenb, H.V. (2010) Enhancing Water and Fertilizer Saving without Compromising Rice Yield through Integrated Crop Management. Indonesian Journal of Agricultural Science, 11, 65-73. https://doi.org/10.21082/ijas.v11n2.2010.p65-73

[30] Talpur, M.A., Ji, C., Junejo, S.A., Tagar, A.A. and Ram, B.K. (2013) Effect of Different Water Depths on Growth and Yield of Rice. African Journal of Agricultural Research, 8, 4654-4659. https://doi.org/10.5897/AJAR12.1693

[31] Dahmardeh, K., Rad, M.R.N. and Hadizadeh, M. (2015) Effects of Potassium Rates and Irrigation Regimes on Yield of Forage Sorghum in Arid Regions. International Journal of Agronomy and Agricultural Research, 6, 207-212.

[32] Ceesay, M., Reid, W.S., Fernandes, E.C. and Uphoff, N.T. (2006) The Effects of Repeated Soil Wetting and Drying on Lowland Rice Yield with System of Rice Intensification (SRI) Methods. International Journal of Agricultural Sustainability, 4, 5-14. https://doi.org/10.1080/14735903.2006.9686007

[33] Barker, R., Dawe, D. and Inocencio, A. (2003) Economics of Water Productivity in Managing Water for Agriculture. In: Kinje, J.W., Barker, R. and Molden, D., Eds., Limits and Opportunities for Improvements, CABI, Oxford, 19-36. https://doi.org/10.1079/9780851996691.0019

[34] Visperas, R.M., Bouman, B.A.M., Peng, S. and Castan, A.R. (2005) Yield and Water Use of Irrigated Tropical Aerobic Rice Systems. International Rice Research Institute, 74, 87-105.

[35] Abdul-Ganiyu, S., Kyei-Baffour, N., Agyare, W. and Dogbe, W. (2015) An Evaluation of Economic Water Productivity and Water Balance of Dry Season Irrigated Rice under Different Irrigation Regimes in Northern Ghana. African Journal of Applied Research, 1. 